\title{
Role of resistin in cardiovascular diseases: Implications for prevention and treatment
}

\author{
Maciej Rachwalik ${ }^{1, A-F}$, Magdalena Hurkacz ${ }^{2, A-F}$, Beata Sienkiewicz-Oleszkiewicz ${ }^{2, A, B, E, F}$, Marek Jasiński, ${ }^{1,3, E, F}$ \\ 1 Department and Clinic of Cardiac Surgery, Wroclaw Medical University, Poland \\ 2 Department of Clinical Pharmacology, Wroclaw Medical University, Poland \\ ${ }^{3}$ Children's Memorial Pediatric Health Institute, Warszawa, Poland \\ A - research concept and design; $\mathrm{B}$ - collection and/or assembly of data; $\mathrm{C}$ - data analysis and interpretation; \\ $\mathrm{D}$ - writing the article; $\mathrm{E}$ - critical revision of the article; $\mathrm{F}$ - final approval of the article
}

\section{Address for correspondence}

Maciej Rachwalik

E-mail: maciej.rachwalik@umed.wroc.pl

Funding sources

None declared

Conflict of interest

None declared

Received on February 4, 2021

Reviewed on April 13, 2021

Accepted on April 20, 2021

Published online on July 20, 2021

\begin{abstract}
Cardiovascular diseases (CVDs) are associated with socioeconomic and, most importantly, with clinical problems. Accordingly, the identification of early and specific biomarkers indicating metabolic changes that underlie disease development and/or progression is important and may improve preventive and treatment strategies. A recently discovered protein - resistin (ADSF, FIZZ3) - whose expression is increased in carbohydrate metabolism and adipose tissue disorders, seems to be worth of interest in this context. The current publication was based on a detailed review of available literature, including Medline, EBSCO, Scopus, and Cochrane Library databases. The search period was between January 1, 2001 and December 20, 2020. The following keywords were used: "resistin", "resistin AND cardiology" and "resistin AND cardiosurgery". Our review covered a total of 4476 records, 594 of which were review publications. The presented article summarizes the current knowledge on the role of resistin in prevention and treatment of CVDs. Available literature shows that resistin may be a predictor for various pathological states; however, data from some studies on the pathophysiological mechanisms of action are contradictory. There is a need for further investigations to explore the exact role of resistin in CVDs.
\end{abstract}

Key words: cardiovascular diseases, atherosclerosis, adipose tissue, cardiac surgery, resistin

Cite as

Rachwalik M, Hurkacz M, Sienkiewicz-Oleszkiewicz B,

Jasiński M. Role of resistin in cardiovascular diseases:

Implications for prevention and treatment. Adv Clin Exp Med.

2021;30(8):865-874. doi:10.17219/acem/135978

DOI

10.17219/acem/135978

Copyright

Copyright by Author(s)

This is an article distributed under the terms of the

Creative Commons Attribution 3.0 Unported (CC BY 3.0)

(https://creativecommons.org/licenses/by/3.0/) 


\section{Introduction}

Over the last decade, the cultural and lifestyle changes in western civilizations and also the progressive aging of society led to a huge increase in the prevalence of diseases resulting from these phenomena. This causes tremendous financial costs that need to be incurred to ensure proper medical care and quality of life for all patients.

According to the World Health Organization (WHO) report, 55\% of all 55.4 million deaths in 2019 were caused by 10 diseases that belong to 3 groups - cardiovascular (coronary artery disease (CAD) and stroke), pulmonary and neonatal diseases. Coronary artery disease is the leading cause of mortality accounting for $16 \%$ of all deaths. ${ }^{1}$ Scientific research conducted in the $20^{\text {th }}$ and $21^{\text {st }}$ century led to the discovery of a number of agents (e.g., proteins such as neopterin, resistin and adiponectin) that are having a direct and indirect impact on the course of the abovementioned diseases. Deeper knowledge is gained about the pathophysiological mechanisms in cells leading to metabolic diseases. This may enable better patient outcome and disease prevention.

This publication aims to assess the current knowledge on resistin as a biomarker in the prevention and treatment of heart diseases. Moreover, we will discuss the usefulness of measuring resistin level in everyday cardiological and cardiosurgical practice. We assessed the available scientific publications documenting the use of resistin as a biomarker for heart diseases and measurement of resistin levels for cardiovascular event screening in populations with risk factors.

\section{Methodology}

This article provides a review of the current publications (published until December 20, 2020). The following databases were searched using selected keywords and Medical Subject Headings (MeSH): Medline (using PubMed and EBSCO), Cochrane Library and Ovid Embase. The search terms were "resistin" and its synonyms (for example "adipose tissue-specific secretory factor", "adipocyte cysteine-rich secreted protein FIZZ3", "ADSF”, "FIZZ3", "FIZZ3 protein", "protein found in inflammatory zone 3", "adipocyte-secreted factor", "adipocyte-specific secreted factor"). To achieve a comprehensive assessment, we did not state the date for the first publication and also performed a manual search. In PubMed, the term "resistin" yielded 4476 records (594 review articles). In 2020, 308 articles were published (31 reviews). Using the keywords "biomarkers AND cardiovascular prevention" to search for publications in databases resulted in 14,271 records (1198 in 2020). The term "resistin AND cardiology" generated 185 publications (17 published in 2020). The term "resistin AND cardiac surgery" resulted in 53 articles (5 published in 2020). In the Scopus database, the term "resistin" appeared in 6911 publications (445 published in 2020) and the term "resistin AND cardiology" in 28 articles. Precisely 1402 records were reviews (6 of them published in 2020). In the Cochrane Library, the term "resistin" generated 526 results, while the term "resistin AND cardiology" 5 results. All of the articles were listed in the "trials" category. Additionally, a detailed search for publications was carried out using the keyword "resistin AND cardiovascular prevention AND biomarkers". In the PubMed database, 55 results were obtained, including only 7 for 2020 . Similar keywords were used in the Scopus database search engine. Two hundred thirty-eight results for this query were obtained, of which 25 were published in 2020. In the EBSCO database, there were 80 and 7 results, respectively. There were no review publications.

The results of various studies show that there is a huge scientific interest in the role of resistin in the etiology of diseases, especially cardiovascular ones, but the usefulness of resistin as a biomarker in cardiac surgery is not fully established yet.

\section{Results}

The review of the publication database results indicates that most of the works focus on the current knowledge how this protein impacts the pathophysiological mechanism of various diseases. The few studies that tried to apply the knowledge of resistin levels as a prognostic factor for various phenomena in patients with heart disease seem to be promising. It is important to note that resistin can be obtained from both peripheral blood and adipose tissue, especially the epicardial adipose tissue. This opens potential pathways for future in-depth diagnosis of heart diseases and the use of resistin tests as a screening biomarker in cardiology and cardiac surgery. The results of several published studies will be presented in this paper.

\section{Discovery of resistin, its structure and role in disease epidemiology}

Adipokines are proteins structurally similar to cytokines and play an important role as biomarkers for lipid metabolism disturbances. Research performed on the influence of obesity on hormone secretion and metabolic syndrome development showed that adipose tissue plays an important role not only as a storage depot but also as a specific endocrine organ secreting functional proteins participating in different regulatory functions of the organism. The discovery of the RETN gene (encoding resistin) confirmed this function. ${ }^{2}$ RETN (ADSF, FIZZ3, RETN1) was first discovered in mouse immune system genes. In humans, it is located on chromosome 19p13.2 and has 4 exons (the length of resistin pre-peptide in humans is 108 amino acid residues and it is 114 in mice). The first one has an approximate length of 1750 base pairs. The characteristic feature of this 
family is the C-terminal stretch of 10 cysteine residues with identical spacing. ${ }^{3}$ The mouse homolog of this protein is secreted by adipocytes and may be correlated with obesity and type 2 diabetes (T2D) development. ${ }^{4}$ Genetic tests showed the presence of mRNA in the adipose tissue. Its expression is $418 \%$ higher in the abdominal adipose tissue than in adipose tissue from other parts of the body, for example from the thighs. McTernan et al. correlated this phenomenon with a greater risk of T2D and obesity. ${ }^{5}$

Resistin was discovered by Steppan et al. in 2001 while studying a new class of antidiabetic drugs - glitazones. ${ }^{6}$ At the same time, Kim et al. showed that this protein secreted by adipocytes inhibits the proliferation of adipose cells. ${ }^{7}$ Other authors discovered that resistin is one of the inflammation factors that have an impact on the reactivation of the respiratory system. ${ }^{8}$ Before these studies were published, the main scientific interests focused on resistin as a factor influencing insulin resistance. Nowadays, it is thought to be a protein playing an important role in various pathomechanisms. The name resistin originates from the phrase "resistance to insulin". It is one of the resistin-like molecules (RELMs) proteins and was first discovered in mouse peripheral blood. ${ }^{9}$ Different names for this protein can be found in the literature with resistin being the most frequently used followed by adipose-specific secretory factor (ADSF) and "protein found in inflammatory zone 3 " (FIZZ3). ${ }^{10}$

The RELMs may influence signal pathways on a cell level, leading to changes in the concentrations of a variety of substances in tissues. Resistin has a multidirectional effect. Through its influence on the metabolism, it antagonizes the action of insulin and reduces glucose level in adipocytes and muscle cells. ${ }^{8}$

Resistin has 2 conformations: a trimer with molecular mass of $45 \mathrm{kDa}$ and an oligomer with a molecular mass of $660 \mathrm{kDa}$. The influence of those 2 conformations on the activity of resistin has not yet been established. ${ }^{11}$ The protein is present in the serum as oligomers with high or low molecular masses. ${ }^{12}$ The multidirectional action of resistin on the metabolism is pleiotropic and directed through 3 mechanisms, i.e., paracrine, endocrine and autocrine mechanisms. ${ }^{13}$

It was shown that resistin is produced in human immune system cells, such as granulocytes, macrophages and monocytes. Moreover, the activity of this protein was observed in hematopoietic stem cells, the spleen, thymus, skeletal muscle system, digestive system, pancreas, placenta, and uterus. ${ }^{14}$ More recent studies showed that RETN gene polymorphism may affect the course of treatment, especially in oncology. ${ }^{15}$ It is suspected that a large number of cells and tissues may react to circulating resistin, which suggests that the protein may have an impact on a wide variety of pathological and physiological processes.

Resistin influences the inhibition of leptin activity through regulating the signal pathway inhibitor expression. ${ }^{16}$ There is evidence that higher levels of this protein in adipose tissue promote the development of insulin resistance that is one of the components of metabolic syndrome (MetS). This is now actively studied. Resistin changes the metabolism of carbohydrates, influencing liver enzyme activity. Banerjee et al. showed that resistin changes the activity of 5'AMPactivated protein kinase in the liver. The decrease of activity is connected with adenosine monophosphate (AMP) phosphorylation, which causes an increase in glucose release in the liver. ${ }^{16}$ This protein accumulates in perivascular adipose tissue (PVAT). This tissue is endocrinally independent of other hormone influences according to studies. In dietinduced obesity, the dysfunction of PVAT leads to vascular diseases. Perivascular adipose tissue contains adipocytes, preadipocytes, mesenchymal stem cells, endothelial cells, and inflammatory cells. Mesenchymal stem cells from PVAT may differentiate into adipocytes, osteoblasts and endothelial cells. The composition of adipose tissue in obesity is different in different people in a given population, and the number of macrophages and lymphocytes $\mathrm{T}$ increases. This phenomenon is still being studied. Numerous inflammatory mediators released from epicardial adipose tissue (EAT) may affect the dynamics of atherosclerosis (AS) and ischemic heart disease (IHD) development.

\section{Reference values of resistin levels in normal and pathological conditions}

Resistin levels in healthy individuals are within the range of 7-22 ng/mL, and are on average $15 \mathrm{ng} / \mathrm{mL}$. They increase with age and underlying pathological conditions, e.g., in diabetes it is $40 \mathrm{ng} / \mathrm{mL} .{ }^{17}$ Resistin levels depend on metabolic changes in the organism. According to Rajala et al., resistin levels are lower in a fasting state than after meals. ${ }^{18}$ Obese individuals have higher resistin concentrations than slim ones. ${ }^{19,20}$ Persons with diabetes and obese patients have increased plasma resistin levels. ${ }^{12}$ In patients with MetS, the levels of this protein correlate with the levels of inflammation biomarkers and CAD. ${ }^{21}$ In patients with osteoarthritis and rheumatoid arthritis, resistin levels are increased in the synovial fluid and tissue. ${ }^{22}$

\section{The impact of resistin levels on insulin levels}

One of the first observations related to resistin was that the levels of this protein were higher in mice with genetic or experimentally generated obesity. ${ }^{9}$ In rats, resistin levels were higher in insulin resistance related to hepatic disturbances. The protein may influence the apoptosis of beta cells in their pancreas. ${ }^{23,24}$ The extrapolation of this data to humans is difficult because of the different histologic composition of the adipose tissue, and the fact that the protein is synthesized in circulating blood monocytes. In contrast to mice, the synthesis of resistin in human white adipose tissue does not play an important role. It is worth mentioning that human and mouse resistin are approx. $60 \%$ homologous. Resistin has the ability to bind 
the suppressor of cytokine signal proteins (SOCS), which are negative regulators of the JAK-STAT signal pathway. A correlation was found in relation to both dose and time. Through resistin induction, SOCS may increase insulin resistance, which corresponds to the impact of resistin on insulin activity in adipocytes. ${ }^{25}$

A study by Sheng et al. showed that the expression of resistin in hepatocytes leads to the development of insulin resistance in humans. ${ }^{26}$ Resistin mRNA levels are higher in patients with T2D than in healthy volunteers. ${ }^{27}$ Gharibeh et al. compared obese patients not suffering from T2D and those with diabetes. Higher levels of resistin were found in the latter group. ${ }^{28}$ In patients with T2D and diabetic foot, resistin levels were even higher than in diabetic patients without this complication. In comparative studies conducted among obese people and patients with T2D, resistin expression was higher in the former, but not in the latter group. ${ }^{29}$ In another study, a correlation of higher resistin levels and T2D was found. Moreover, a correlation with complications of gestational diabetes was found. ${ }^{11}$ More studies on the impact of resistin levels on insulin resistance pathogenesis are needed to establish them as insulin resistance biomarkers in different patient groups.

\section{Impact of resistin on the etiology of thrombosis}

Recent studies show that in the pathophysiological mechanism of myocardial infarction (MI), thrombus building on the surface of plaque seems to play a key role in coronary arteries. Resistin probably plays an important role in this process, too. This role is connected with its influence on NO synthesis. Present theories pertain to the regulatory function of resistin on the endothelial nitric oxide synthase (eNOS) enzyme. This enzyme generates NO in the endothelium through the conversion of L-arginine into L-citrulline. The NO plays a role in platelet activity and in vivo studies are ongoing. Endogenous NO generated by eNOS is an important regulator of in vivo platelet activity in the vascular endothelium and has a minimal impact on inducible NOS and neuronal NOS. ${ }^{30}$ The abovementioned theories need further validation in animal models. Resistin and oxidative stress may play a role in the pathogenesis of CAD, including acute coronary syndrome (ACS). The influence of resistin levels on the oxidativereductive balance was evaluated in ACS to distinguish it from stable angina. Patients with ACS had higher resistin levels than those with stable angina $(2.55 \pm 0.13 \mathrm{ng} / \mathrm{mL}$ compared to $1.53 \pm 0.12 \mathrm{ng} / \mathrm{mL}$, respectively; $\mathrm{p}<0.001){ }^{31}$

\section{The impact of resistin levels on kidney diseases}

A relationship between hyperresistinemia and renal function impairment was established in 2009. ${ }^{32}$ Through the stimulation of proper signal pathways, cytokines may influence binding on the cell surface and triggering signal pathways. In this way, they may influence cell function. The cytokine response takes place through the change in the number of receptors on the cell surface, regulation of the synthesis of other cytokines, and the change in gene activity and transcription. ${ }^{33}$ Resistin influences the synthesis and release of endothelin-1 (ET-1) from endothelial cells, increases the production of cell adhesion molecules, and may decrease the synthesis of factor 3 connected with the tumor necrosis factor alpha (TNF- $\alpha$ ) receptor. Endothelin-1 is a vascular factor synthesized in the endothelium that may be related to the development of AS. ${ }^{34}$

\section{The impact of resistin levels on other diseases}

In current studies, resistin is also thought to be connected with different cardiovascular diseases (CVDs), especially IHD. ${ }^{35}$ Other studies show its potential relationship with oncologic diseases, asthma, Crohn's disease, and T2D. ${ }^{32}$ Higher resistin levels were observed in patients with kidney failure. ${ }^{36}$ Active cancer is connected with higher resistin activity, which may have an impact on its progression. ${ }^{37}$ Resistin and other adipokines play an increasingly important role in the diagnosis of oncologic diseases. The research in the last 2 decades showed that their higher levels in serum are affecting breast cancer development in women with pre-existing obesity. Wang et al. showed a correlation between resistin levels and frequency of stromal tumor in breast cancer, especially in postmenopausal women with obesity. ${ }^{38}$ Resistin together with other adipokines may be used as a predictor for complex breast cancer risk assessment in women. ${ }^{39}$ Figure 1 shows the main mechanisms related to the influence of resistin on the human body and diseases in which it may play an important role.

\section{Resistin as a potential biomarker of cardiovascular diseases treatment and prevention}

\section{The impact of resistin levels on the development of atherosclerosis}

Cardiovascular diseases, especially IHD, are a leading cause of death in today's world. Atherosclerosis is an inflammatory disease. Monocytes migrate to the arterial endothelium where they differentiate into macrophages. The next step in this process is the invasion of large amounts of lipoproteins and further differentiation into foam cells, which may form a plaque. Importantly, resistin is synthesized not only in human adipocytes but also in macrophages. ${ }^{40}$ This is supported by the fact that high resistin levels were observed in patients with ACS, where 


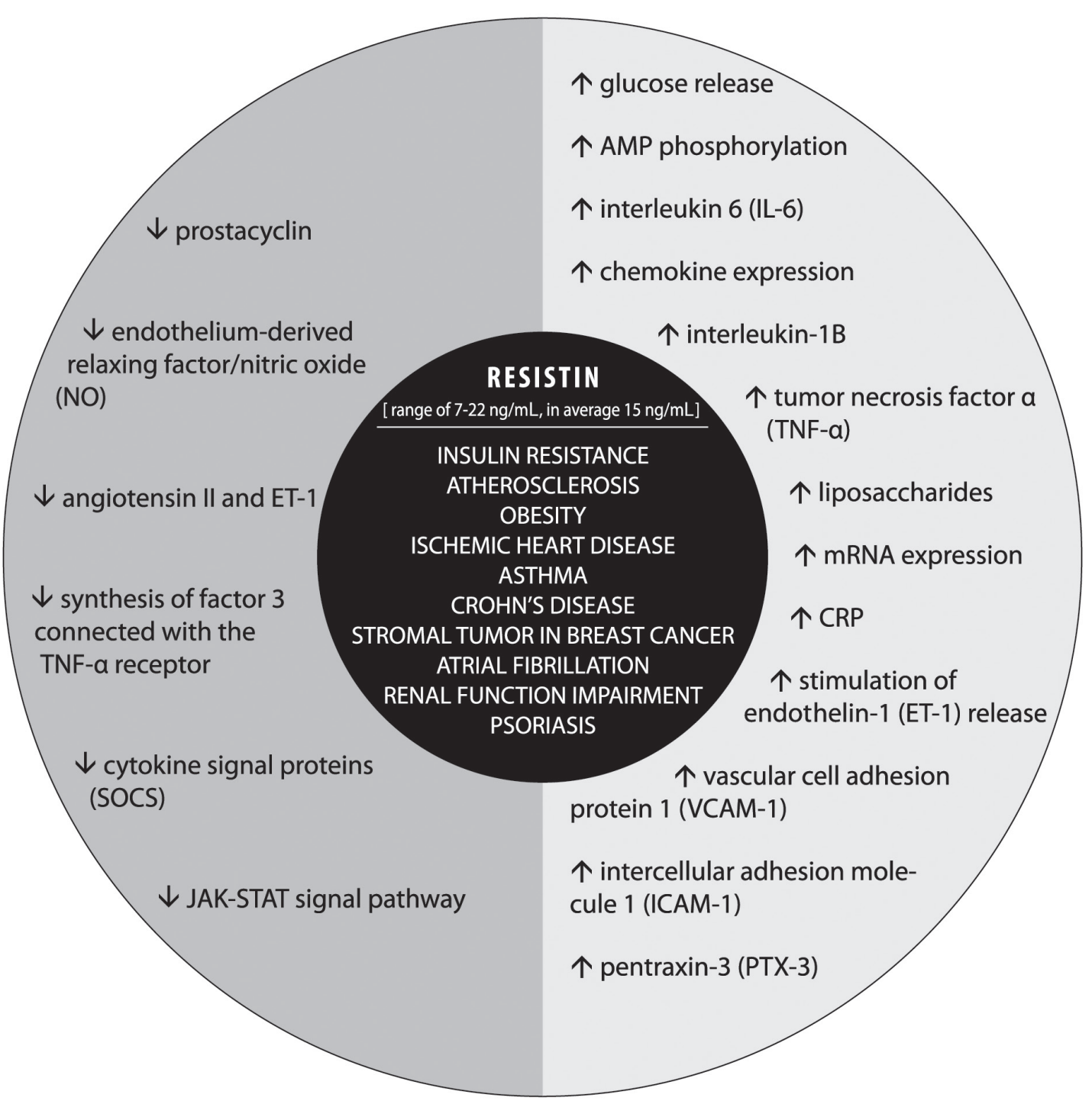

Fig. 1. The main mechanisms related to the influence of resistin on the human body and diseases in which it may play an important role

damage from plaques occurs. The cells infiltrate arteries and are a source of cytokines. As an adipokine, resistin induces cytokine and chemokine expression. ${ }^{41}$

Many studies showed a correlation between IHD and changes in plasma resistin levels as well as in pericardial perivascular tissue. Wang et al. showed higher plasma resistin levels in patients with ACS..$^{42}$ In a group of 220 patients with ACS, resistin levels were higher than in patients that qualified for elective cardiac procedures $(1.18 \pm 0.48 \mu \mathrm{g} / \mathrm{L}$ compared to $0.49 \pm 0.40 \mu \mathrm{g} / \mathrm{L} ; \mathrm{p}<0.01)$. $\mathrm{Hu}$ et al. published similar observations. In a group of 93 patients with ACS, resistin levels in patients with unstable angina were $12.09 \mathrm{ng} / \mathrm{mL}$ compared to $9.04 \mathrm{ng} / \mathrm{mL}$ in patients without signs of instability. Higher resistin levels were a syndrome of unstable angina. However, this study did not reveal a positive correlation between resistin concentrations and hypertension. ${ }^{43} \mathrm{~A}$ positive correlation between resistin levels and high sensitivity C-reactive protein (CRP) levels and white blood cells (WBC) count was observed, which was also reported by other scientists. ${ }^{44,45}$

\section{The impact of resistin levels on the etiology of atherosclerosis and endothelial function}

The complicated mechanism of AS leads to an increase of lipid storage in blood vessels, proliferation of smooth muscle tissue cells, inflammatory cell invasion, and finally inflammation of blood vessels. Ischemic heart disease is caused by the progressive development of strictures in coronary vessels in the form of plaques, which are the places of damage and blood vessel stenosis. Literature shows that this process may be influenced by serum resistin levels. ${ }^{46}$

Initially, resistin was only associated with the influence on insulin resistance development. Further studies showed that the protein is involved in inflammatory processes in in vitro and in vivo conditions. Positive feedback is observed between the level of resistin and pro-inflammatory proteins such as interleukin (IL)-1B, IL-6, TNF- $\alpha$, and liposaccharides, which significantly increase the expression 
of resistin in peripheral blood mononuclear cells. ${ }^{47}$ Resistin takes part in the communication between adipocytes and inflammatory cells. ${ }^{48}$ An increase of mRNA expression and CRP secretion by peripheral blood mononuclear cells (PBMC) was shown. ${ }^{49}$

Free radicals are involved in the atherosclerotic process. Their production is connected with hyperresistinemia, the migration of monocytes to the inner membrane of the coronary vessels and their differentiation into macrophages. The consequence of monocyte migration is their stepwise differentiation into foam cells that accumulate the oxidated form of low-density lipoproteins (LDL). An additional factor of plaque formation is endothelial dysfunction. The process is multifactorial and modulated by cytokines, free radicals, growth factors, and cell adhesion molecules (influencing the tension of the coronary vascular wall and leukocyte adhesion). ${ }^{11}$ In the development of AS, the mechanisms that mediate the adhesion, and release of inflammatory and anti-inflammatory cytokines are not fully known. Resistin may play a role in endothelial dysfunction through stimulation of ET-1 release. ${ }^{50}$ It induces the expression of adhesive molecules, such as vascular cell adhesion protein 1 (VCAM-1), intercellular adhesion molecule 1 (ICAM-1) and pentraxin-3 (PTX-3), a pneumonia biomarker. Other proteins that inhibit the release of VCAM-1 and ICAM-1, additionally lowering insulin resistance, such as adiponectin, stand in contrast to the proatherogenic action of resistin. This shows that there is a balance between pro- and antiatherogenic factors; a balance between serum levels of resistin and adiponectin. An imbalance influences the development or inhibition of AS. ${ }^{51}$ Endothelial dysfunction and endoplasmic reticulum stress was shown to influence resistin mRNA levels in a special mouse adipocyte cell line (3T3-L1) leading to the progression of AS in this model. ${ }^{52}$ Coronary endothelial cells constitute a protective barrier against pathophysiological phenomena promoting AS. Prostacyclin, endothelium-derived relaxing factor/NO, angiotensin II, and ET-1 are substances synthesized and released by endothelial cells supporting their secretory properties. ${ }^{53}$ The tight arrangement of the endothelial cells in the coronary vessels is additionally strengthened by endothelial cell junctions. Damage to this barrier leads to higher permeability for monocytes, macrophages, leucocytes, and cholesterol-transporting lipoproteins. ${ }^{54}$ It was shown in a rabbit artery model that resistin synthesized in macrophages leads to the adhesion of monocytes to endothelial cells through the integration of integrin-alpha 4 and beta- 1 in monocytes. This leads to VCAM-1 expression and longer-lasting monocytes on the plaque causing an increase in inflammation. ${ }^{55}$

In vitro studies showed that higher resistin levels may increase the permeability of endothelial cells. Epicardial adipose tissue is indicated as the source of resistin. ${ }^{56}$ Other substances belonging to RELMs, especially RELM-beta, may play a similar role. Similar to resistin, RELM-beta is also a cysteine-rich protein. ${ }^{57}$ Resistin influences also eNOS in endothelial cells. A correlation between the levels of this protein, lower mRNA expression and enzyme activity was shown. Nitric oxide concentration negatively correlated with resistin levels. The protein from endothelial cells increases the synthesis of reactive oxygen species (ROS) and suboxide anions. ${ }^{58}$

Kougias et al. showed that resistin acts as a pro-oxidant in endothelial dysfunction through lowering eNOS expression. A decrease of endothelial-dependent and independent vasorelaxation was noticed in prepared porcine coronary artery rings in vitro. This effect was significant when high levels of resistin $(>40 \mathrm{ng} / \mathrm{mL})$ were used. ${ }^{59}$ Dick et al. confirmed the previously mentioned results using coronary arteries of dogs under general anesthesia and prepared parts of canine coronary artery rings. Resistin decreased the bradykinin-induced vasorelaxation, which led to the conclusion that this protein may influence the metabolism of endothelial cells. The experiment did not show that endothelial dysfunction caused by resistin influences the development of AS and the decrease of bradykinin activity was reported as moderate. ${ }^{60}$ There are also some doubts as to whether the influence of resistin on human coronary arteries is the same as in other species such as pigs or dogs. Studies in mice were also performed. Transverse aortic vascular rings of mice $(\mathrm{C} 57 \mathrm{BL} / 6$; $\mathrm{n}=22)$ were exposed to various biological factors, including resistin. A decrease in vasorelaxation caused by insulin was observed. According to scientists, resistin acts mainly in the endothelium through the insulin-mediated IRS1 signal pathway, leading to Akt/eNOS phosphorylation and, in consequence, a decrease of NO-dependent vasorelaxation. ${ }^{61}$ The abovementioned studies showed that resistin changes the vasomotor functions of coronary arteries in vivo and in vitro.

In 2014, Cabrera de Leon et al. published the results of a study on the impact of resistin levels on the occurrence of cardiovascular events. The study was conducted in a group of 6636 randomly selected people. It was shown that resistin levels in women were higher than in men, and, regardless of gender, these levels correlated with the frequency of cardiovascular events. The researchers also assessed other factors, such as: arterial hypertension, abdominal obesity, diabetes, dyslipidemia, and smoking. ${ }^{62}$

In 2015, Gencer et al. published a summary of results from a ten-year follow-up on the relationship between resistin and cardiovascular events. Exactly 3044 people aged 70-79 participated in the study. Cardiovascular events were defined as heart disease or stroke, whereas severe events were defined as death or MI. There was a significant correlation between the frequency and severity of cardiovascular events and plasma resistin levels. ${ }^{63}$ Muse et al. investigated the relationship between resistin levels and the incidence of cardiovascular events in various ethnic groups in 1913 people, and found that the Hispanic group presented with a higher risk of cardiovascular events, which correlated with resistin levels. ${ }^{64}$ 
Resistin can be used as a peripheral blood biomarker for strokes. In a study performed in 46 patients with ischemic stroke, higher levels of resistin and chemerin (another adipokine) were noticed. Higher levels of resistin and chemerin significantly increased the risk of ischemic stroke. The severity of stroke was not influenced by the levels of the aforementioned adipokines. ${ }^{65}$

In a group of patients with heart diseases requiring surgical intervention, levels of pro-inflammatory proteins were measured before and after the surgical procedure. The study showed that higher resistin levels correlated with blood transfusions after valve replacement surgery and revascularization of the heart muscle. ${ }^{66}$

In the AVOCADO study (Aspirin Vs./Or Clopidogrel in Aspirin-resistant Diabetics inflammation Outcomes), patients with T2D and at least 2 other cardiovascular risk factors and receiving acetylsalicylic acid were examined. It was noted that patients with atrial fibrillation (AF) presented higher levels of resistin and adiponectin than patients without AF. However, none of the analyzed adipokines was a predictive factor for AF development. ${ }^{67}$

In another study carried out in 146 patients, resistin was indicated to play a potentially predictive role as a biomarker for AF. Twenty eight patients with AF presented higher serum resistin levels. ${ }^{68}$

There is a practical aspect of measuring resistin levels in epicardial tissue (sectioned during cardiovascular surgery) as that may be an indirect predictor for AF during postoperative care. In our previous study, 46 patients after coronary artery bypass grafting (CABG) were monitored for 3 days after the surgery and divided into 2 groups (with AF after the surgery and without AF after surgery). Resistin levels in perivascular adipose tissue in the area of the left coronary artery were significantly higher in patients with AF than in those without AF $(p=0.03)$. Multivariate stepwise regression analysis showed that resistin levels higher than $54 \mathrm{ng} / \mathrm{g}$ in the PVAT of the left coronary artery were independently connected with AF in the postoperative period. ${ }^{69}$ Resistin may also be a biomarker for cardiovascular events in patients undergoing cardiosurgical procedures. In a study with 33 patients that had CAD after cardiac surgery, the patients were divided into 2 groups, in which the $1^{\text {st }}$ group included patients that underwent MI in the past while the patients in the $2^{\text {nd }}$ group did not. Epicardial fat tissue was collected from all patients during cardiac surgery. Multivariate analysis showed that MI correlated with being male, older age, and higher resistin levels in epicardial fat tissue compared to potentially healthy persons. ${ }^{70}$

The influence of resistin on different disease processes in the human body is multidirectional and leads to negative outcomes. This is why resistin may be a potential target for new therapeutic strategies. However, the role of resistin in pathophysiology needs to be fully evaluated. A potential method for this evaluation is the use of a new antibody against human resistin (hResistin). It may be used for the immunohistochemical evaluation of hResistin expression, localization and intracellular/extracellular compartmentalization in human tissues. The cross-sectional reactivity of this monoclonal antibody against hResistin immunoglobulin G1 class (IgG1) with proper human tissues was also verified. The results show that hesistin is widely spread and localized mainly in cytoplasmic macrophage granules in the interstitial parts of most human tissues. Marked hResistin was also observed in the cytoplasm of nervous system cells. Data show that the antibody binds to human resistin and may be potentially used in immunotherapy aiming to decrease free circulating hResistin levels in patients. ${ }^{71}$

In the etiology of CVDs, obesity and insulin resistance play a vital role. The treatment of those diseases

Table 1. Human studies showing evidence for the role of resistin in cardiac diseases

\begin{tabular}{|c|c|c|c|}
\hline Analysis & Group & Evidence & References \\
\hline $\begin{array}{l}\text { Various markers, plasma } \\
\text { resistin levels }\end{array}$ & 6636 people (randomly selected) & $\begin{array}{l}\text { Resistin levels correlated with the frequency } \\
\text { of cardiovascular events }\end{array}$ & Cabrera et al. ${ }^{62}$ \\
\hline Plasma resistin levels & 3044 people aged 70-79 & $\begin{array}{l}\text { Positive significant correlation with } \\
\text { cardiovascular events }\end{array}$ & Gencer et al. ${ }^{63}$ \\
\hline $\begin{array}{l}\text { Resistin levels, different } \\
\text { ethnic groups }\end{array}$ & 1913 people from various ethnic groups & $\begin{array}{l}\text { Resistin plasma levels correlated with } \\
\text { the incidence of cardiovascular events } \\
\text { in the Hispanic group }\end{array}$ & Muse et al. ${ }^{64}$ \\
\hline $\begin{array}{l}\text { Peripheral blood resistin } \\
\text { levels }\end{array}$ & 46 patients with ischemic stroke & $\begin{array}{c}\text { Higher levels of resistin significantly increased } \\
\text { the risk of ischemic stroke }\end{array}$ & Kazimierczak-Kabzińska et al. ${ }^{65}$ \\
\hline $\begin{array}{l}\text { Various protein levels } \\
\text { before and after surgical } \\
\text { procedure }\end{array}$ & $\begin{array}{l}90 \text { patients divided into } 3 \text { groups } \\
\text { undergoing open heart surgeries }\end{array}$ & $\begin{array}{l}\text { Higher resistin levels correlated with blood } \\
\text { transfusion after valve replacement surgery } \\
\text { and revascularization of the heart muscle }\end{array}$ & Saracevic et al. ${ }^{66}$ \\
\hline AVOCADO study & $\begin{array}{c}304 \text { patients with type } 2 \text { diabetes with } 2 \\
\text { additional cardiovascular risk factors and } \\
\text { receiving acetylsalicylic acid }\end{array}$ & $\begin{array}{c}\text { In type } 2 \text { diabetes, patients with AF had } \\
\text { higher resistin concentrations than patients } \\
\text { with no AF }\end{array}$ & Peller et al. ${ }^{67}$ \\
\hline Serum resistin levels & 146 patients with AF & $\begin{array}{l}\text { Resistin may play predictive role as biomarker } \\
\text { for AF }\end{array}$ & Samanidis et al. ${ }^{68}$ \\
\hline
\end{tabular}

AF - atrial fibrillation 
is connected with the use of statins which minimize the incidence of CVDs. Statins may be used in patients with T2D because they decrease resistin mRNA levels in PBMC and plasma resistin levels. ${ }^{72}$ In addition, resistin plasma levels may also be decreased by the use of ramipril or amlodipine. ${ }^{73}$ Promising reports show that those levels may also be decreased by the bolus administration of vitamin $\mathrm{C}$ that leads to lower oxidative stress. ${ }^{74} \mathrm{~A}$ similar effect was observed in psoriasis patients treated with retinoids. ${ }^{75}$

The review of available publications showed that the role of resistin as a marker in the etiology and treatment for heart diseases has increased in recent years, but the main interest lies in its role in metabolic, renal and oncological diseases. In the near future, new scientific data can be expected, which will also include issues related to cardiac surgery.

Table 1 provides an overview of relevant publications on the potential use of resistin as a biomarker in the treatment and prevention of heart diseases.

\section{Conclusions}

Publications show that resistin may be a predictor for various pathological states. Not all studies present precise and coherent data on the pathophysiological mechanisms of action. There is a need for further studies to explain the exact role of resistin in many diseases. Resistin could be a biomarker for cardiovascular events in patients undergoing cardiosurgical procedures. On the other hand, this protein may be a potential target for new therapeutic strategies.

\section{ORCID iDs}

Maciej Rachwalik (1) https://orcid.org/0000-0001-9714-4059 Magdalena Hurkacz (1) https://orcid.org/0000-0003-0846-3168 Beata Sienkiewicz-Oleszkiewicz (1) https://orcid.org/0000-0003-1912-0873 Marek Jasiński (i) https://orcid.org/0000-0002-9989-7748

\section{References}

1. WHO reveals leading causes of death and disability worldwide: 2000 2019 December 2020. Geneva, Switzerland: World Health Organization; 2020. https://www.who.int/news/item/09-12-2020-whoreveals-leading-causes-of-death-and-disability-worldwide-2000-2019. Accessed December 8, 2020.

2. Fasshauer M, Blüher M. Adipokines in health and disease. Trends Pharmacol Sci. 2015;36:461-470. doi:10.1016/j.tips.2015.04.014

3. Wang H, Chu WS, Hemphill C, Elbein SC. Human resistin gene: Molecular scanning and evaluation of association with insulin sensitivity and type 2 diabetes in Caucasians. J Clin Endocrinol Metab. 2002;87(6): 2520-2524. doi:10.1210/jcem.87.6.8528

4. Berger A. Resistin: A new hormon that links obesity with type 2 diabetes. BMJ. 2001;322(7280):193. doi:10.1136/bmj.322.7280.193/c

5. McTernan C, McTernan P, Harte A, et al. Resistin, central obesity, and type 2 diabetes. Lancet. 2002;359(9300):46-47. doi:10.1016/s01406736(02)07281-1

6. Steppan CM, Bailey ST, Bhat S, et al. The hormone resistin links obesity to diabetes. Nature. 2001;409(6818):307-312. doi:10.1038/35053000

7. Kim KH, Lee K, Moon YS, Sul HS. A cysteine-rich adipose tissue-specific secretory factor inhibits adipocyte differentiation. J Biol Chem. 2001;276(14):11252-11256. doi:10.1074/jbc.C100028200
8. Borsuk A, Biernat W, Zięba D. Multidirectional action of resistin in the organism [in Polish]. Postep Hig Med Dosw. 2018;72:327-338.

9. Steppan CM, Brown EJ, Wright CM, et al. A family of tissue-specific resistin-like molecules. Proc Natl Acad Sci U S A. 2001;98(2):502-506. doi:10.1073/pnas.98.2.502

10. Al Hannan F, Culligan KG. Human resistin and the RELM of inflammation in diabesity. Diabetol Metab Syndr. 2015;7:54. doi:10.1186/s13098015-0050-3

11. Codoner-Franch P, Alonso-Iglesias E. Resistin: Insulin resistance to malignancy. Clin Chim Acta. 2015;438:46-54. doi:10.1016/j.cca.2014.07.043

12. Gerber M, Boettner A, Seidel B, et al. Serum resistin levels of obese and lean children and adolescents: Biochemical analysis and clinical relevance. J Clin Endocrinol Metab. 2005;90(8):4503-4509. doi:10.1210/ jc.2005-0437

13. Hsieh YY, Shen $\mathrm{CH}$, Huang WS, et al. Resistin-induced stromal cellderived factor-1 expression through Toll-like receptor 4 and activation of p38 MAPK/NFKB signaling pathway in gastric cancer cells. J Biomed Sci. 2014;21(1):59. doi:10.1186/1423-0127-21-59

14. Patel L, Buckels AC, Kinghorn IJ, et al. Resistin is expressed in human macrophages and directly regulated by PPAR gamma activators. Biochem Biophys Res Commun. 2003;300(2):472-476. doi:10.1016/s0006291x(02)02841-3

15. Wang CQ, Tang $\mathrm{CH}$, Tzeng HE, et al. Impacts of RETN genetic polymorphism on breast cancer development. J Cancer. 2020;11(10): 2769-2777. doi:10.7150/jca.38088

16. Banerjee RR, Rangwala SM, Shapiro JS, et al. Regulation of fasted blood glucose by resistin. Science. 2004;303(5661):1195-1198. doi:10. 1126/science.1092341

17. Fehmann $\mathrm{HC}$, Heyn J. Plasma resistin levels in patients with type 1 and type 2 diabetes mellitus and in healthy controls. Horm Metab Res. 2002;34(11-12):671-673. doi:10.1055/s-2002-38241

18. Rajala MW, Qi Y, Patel HR, et al. Regulation of resistin expression and circulating levels in obesity, diabetes, and fasting. Diabetes. 2004; 53(7):1671-1679. doi:10.2337/diabetes.53.7.1671

19. Nieva-Vazquez A, Pérez-Fuentes R, Torres-Rasgado E, López-López JG, Romero JR. Serum resistin levels are associated with adiposity and insulin sensitivity in obese Hispanic subjects. Metab Syndr Relat Disord. 2014:12(2):143-148. doi:10.1089/met.2013.0118

20. Joun BS, Yu KY, Park HJ, et al. Plasma resistin concentrations measured by enzyme-linked immunosorbent assay using a newly developed monoclonal antibody are elevated in individuals with type 2 diabetes mellitus. J Clin Endocrinol Metab. 2004;89(1):150-156. doi:10.1210/ jc.2003-031121

21. Ohmori R, Momiyama Y, Kato R, et al. Associations between serum resistin levels and insulin resistance, inflammation, and coronary artery disease. J Am Coll Cardiol. 2005;46(2):379-380. doi:10.1016/j. jacc.2005.04.022

22. Schaffler A, Ehling A, Neumann E, et al. Adipocytokines in synovial fluid. JAMA. 2003;290(13):1709-1710. doi:10.1001/jama.290.13.1709-c

23. Rajala MW, Obici S, Scherer PE, Rossetti L. Adipose-derived resistin and gut-derived resistin-like molecule-beta selectively impair insulin action on glucose production. J Clin Invest. 2003;111(2):225-230. doi:10.1172/JCI16521

24. Gao C, Zhao D, Qiu J, et al. Resistin induces rat insulinoma cell RINm5F apoptosis. Mol Biol Rep. 2009;36(7):1703-1708. doi:10.1007/s11033008-9371-8

25. Steppan CM, Wang J, Whiteman EL, Birnbaum MJ, Lazar MA. Activation of SOCS-3 by resistin. Mol Cell Biol. 2005;25(4):1569-1575. doi:10. 1128/MCB.25.4.1569-1575.2005

26. Sheng $\mathrm{CH}$, Di J, Jin $\mathrm{Y}$, et al. Resistin is expressed in human hepatocytes and induces insulin resistance. Endocrine. 2008;33(2):135-143. doi:10.1007/s12020-008-9065-y

27. Tsiotra PC, Tsigos C, Anastasiou E, et al. Peripheral mononuclear cell resistin mRNA expression is increased in type 2 diabetic women. Mediators Inflamm. 2008;2008:892864. doi:10.1155/2008/892864

28. Gharibeh MY, Al Tawallbeh GM, Abboud MM, Radaideh A, Alhader AA, Khabour OF. Correlation of plasma resistin with obesity and insulin resistance in type 2 diabetic patients. Diabetes Metab. 2010;36:443-449. doi:10.3389/fphys.2019.01399

29. Laudes M, Oberhauser F, Schulte DM, et al. Visfatin/PBEF/Nampt and resistin expressions in circulating blood monocytes are differentially related to obesity and type 2 diabetes in humans. Horm Metab Res. 2010;42(4):268-273. doi:10.1055/s-0029-1243638 
30. Moore C, Sanz-Rosa D, Emerson M. Distinct role and location of the endothelial isoform of nitric oxide synthase in regulating platelet aggregation in males and females in vivo. Eur J Pharmacol. 2011;651(1-3): 152-158. doi:10.1016/j.ejphar.2010.11.011

31. Pourmoghaddas A, Elahifar A, Darabi F, Movahedian A, Amirpour A, Sarrafzadegan N. Resistin and prooxidant-antioxidant balance: Markers to discriminate acute coronary syndrome from stable angina. ARYA Atheroscler. 2020;16(2):46-54. doi:10.22122/arya.v16i2.1944

32. Filkova M, Haluzik M, Gay S, Senolt L. The role of resistin as a regulator of inflammation: Implications for various human pathologies. Clin Immunol. 2009;133(2):157-170. doi:10.1016/j.clim.2009.07.013

33. Verma S, Li SH, Wang $\mathrm{CH}$, et al. Resistin promotes endothelial cell activation: Further evidence of adipokine-endothelial interaction. Circulation. 2003;108(6):736-740. doi:10.1161/01.CIR.0000084503.91330.49

34. Verma S, Li SH, Badiwala MV, et al. Endothelin antagonism and interleukin- 6 inhibition attenuate the proatherogenic effects of C-reactive protein. Circulation. 2002;105(16):1890-1899. doi:10.1161/01.cir. 0000015126.83143.b4

35. Libby P, Ridker PM, Hansson GK. Inflammation in atherosclerosis: From pathophysiology to practice. J Am Coll Cardiol. 2009;54(23):2129-2138. doi:10.1016/j.jacc.2009.09.009

36. Axelsson J, Bergsten A, Qureshi AR, et al. Elevated resistin levels in chronic kidney disease are associated with decreased glomerular filtration rate and inflammation, but not with insulin resistance. Kidney Int. 2006;69(3):596-604. doi:10.1038/sj.ki.5000089

37. Dalamaga M, Sotiropoulos G, Karmaniolas K, Pelekanos N, Papadavid E, Lekka A. Serum resistin: A biomarker of breast cancer in postmenopausal women? Association with clinicopathological characteristics, tumor markers, inflammatory and metabolic parameters. Clin Biochem. 2013;46(7-8):584-590. doi:10.1016/j.clinbiochem.2013.01.001

38. Wang YY, Hung AC, Lo S, Yuan SF. Adipocytokines visfatin and resistin in breast cancer: Clinical relevance, biological mechanisms, and therapeutic potential. Cancer Lett. 2021;498:229-239. doi:10.1016/j. canlet.2020.10.045

39. Wu X, Zhang X, Hao Y, Li J. Obesity-related protein biomarkers for predicting breast cancer risk: An overview of systematic reviews. Breast Cancer. 2021;28(1):25-39. doi:10.1007/s12282-020-01182-0

40. Tilg H, Moschen AR. Adipocytokines: Nediators linking adipose tissue, inflammation and immunity. Nat Rev Immunol. 2006;6(10):772-783. doi:10.1038/nri1937

41. Zhang Z, Xing X, Hensley G, et al. Resistin induces expression of proinflammatory cytokines and chemokines in human articular chondrocytes via transcription and messenger RNA stabilization. Arthritis Rheum. 2010;62(7):1993-2003. doi:10.1002/art.27473

42. Wang H, Chen DY, Cao J, He ZY, Zhu BP, Long M. High serum resistin level may be an indicator of the severity of coronary disease in acute coronary syndrome. Chin Med Sci J. 2009;24(3):161-166. doi:10.1016/ s1001-9294(09)60082-1

43. Hu WL, Qiao SB, Hou Q, Yuan JS. Plasma resistin is increased in patients with unstable angina. Chin Med J (Engl). 2007;120(10):871-875. PMID: 17543176

44. Al-Daghri N, Chetty R, McTernan PG, et al. Serum resistin is associated with C-reactive protein \& LDL cholesterol in type 2 diabetes and coronary artery disease in a Saudi population. Cardiovasc Diabetol. 2005;4:10-15. doi:10.1186/1475-2840-4-10

45. Bo S, Gambino R, Pagani A, et al. Relationships between human serum resistin, inflammatory markers and insulin resistance. Int J Obes (Lond). 2005;29(11):1315-1320. doi:10.1038/sj.ijo.0803037

46. Taylor EB. The complex role of adipokines in obesity, inflammation, and autoimmunity. Clin Sci. 2021;135(6):731-752. doi:10.1042/CS20200895

47. Bokarewa M, Nagaev I, Dahlberg L, Smith U, Tarkowski A. Resistin, an adipokine with potent pro-inflammatory properties. J Immunol. 2005;174(9):5789-5795. doi:10.4049/jimmunol.174.9.5789

48. Biscetti F, Nardella E, Cecchini AL, Flex A, Landolfi R. Biomarkers of vascular disease in diabetes: The adipose-immune system cross talk. Intern Emerg Med. 2020;15(3):381-393. doi:10.1007/s11739-019-02270-6

49. Hu WL, Qian SB, Li LJ. Decreased C-reactive protein-induced resistin production in human monocytes by simvastatin. Cytokine. 2007 40(3):201-206. doi:10.1016/j.cyto.2007.09.011

50. Samsamshariat SZA, Sakhaei F, Salehizadeh L, Keshvari M, Asgary S. Relationship between resistin, endothelin-1, and flow-mediated dilation in patient with and without metabolic syndrome. Adv Biomed Res. 2019;8:16. doi:10.4103/abr.abr_126_18
51. Kawanami D, Maemura K, Takeda N, et al. Direct reciprocal effects of resistin and adiponectin on vascular endothelial cells: A new insight into adipocytokine-endothelial cell interactions. Biochem Biophys Res Commun. 2004;6;314(2):415-419. doi:10.1016/j.bbrc.2003.12.104

52. Lefterova MI, Mullican SE, Tomaru T, Qatanani M, Schupp M, Lazar MA. Endoplasmic reticulum stress regulates adipocyte resistin expression. Diabetes. 2009;58(8):1879-1886. doi:10.2337/db08-1706

53. Furchgott RF, Zawadzki JV. The obligatory role of endothelial cells in the relaxation of arterial smooth muscle by acetylcholine. Nature. 1980;288(5789):373-376. doi:10.1038/288373a0

54. Goshima Y, Okada Y, Torimoto K, Fujino Y, Tanaka Y. Changes in endothelial function during educational hospitalization and the contributor to improvement of endothelial function in type 2 diabetes mellitus. Sci Rep. 2020;21;10(1):15384. doi:10.1038/s41598-020-72341-8

55. Cho Y, Lee SE, Lee HC, et al. Adipokine resistin is a key player to modulate monocytes, endothelial cells, and smooth muscle cells, leading to progression of atherosclerosis in rabbit carotid artery. J Am Coll Cardiol. 2011;4;57(1):99-109. doi:10.1016/j.jacc.2010.07.035

56. Langheim S, Dreas L, Veschini L, et al. Increased expression and secretion of resistin in epicardial adipose tissue of patients with acute coronary syndrome. Am J Physiol Heart Circ Physiol. 2010;298:H746-H753. doi:10.1152/ajpheart.00617.2009

57. Mishra A, Wang M, Schlotman J, et al. Resistin-like molecule-beta is an allergen-induced cytokine with inflammatory and remodeling activity in the murine lung. Am J Physiol Lung Cell Mol Physiol. 2007;293(2):L305-L313. doi:10.1152/ajplung.00147.2007

58. Chen C, Jiang J, Lu JM, et al. Resistin decreases expression of endothelial nitric oxide synthase through oxidative stress in human coronary artery endothelial cells. Am J Physiol Heart Circ Physiol. 2010;299(1): H193-H201. doi:10.1152/ajpheart.00431.2009

59. Kougias $\mathrm{P}, \mathrm{Chai} H$, Lin $\mathrm{PH}$, Lumsden AB, Yao Q, Chen C. Adipocytederived cytokine resistin causes endothelial dysfunction of porcine coronary arteries. J Vasc Surg. 2005;41(4):691-698. doi:10.1016/j.jvs. 2004.12.046

60. Dick GM, Katz PS, Farias M III, et al. Resistin impairs endothelium-dependent dilation to bradykinin, but not acetylcholine, in the coronary circulation. Am J Physiol Heart Circ Physiol. 2006;291(6):H2997-H3002. doi:10.1152/ajpheart.01035.2005

61. Gentile MT, Vecchione C, Marino G, et al. Resistin impairs insulin-evoked vasodilation. Diabetes. 2008;57(3):577-583. doi:10.2337/db07-0557

62. Cabrera de Leon A, Gonzalez DA, Gonzalez Hernandez A, et al. The association of resistin with coronary disease in the general population. J Atheroscler Thromb. 2014;21(3):273-281. doi:10.5551/jat.19273

63. Gencer B, Auer R, de Rekeneire N, et al. Association between resistin levels and cardiovascular disease events in older adults: The health, aging and body composition study. Atherosclerosis. 2016;245:181-186. doi:10.1016/j.atherosclerosis.2015.12.004

64. Muse ED, Feldman DI, Blaha MJ, et al. The association of resistin with cardiovascular disease in the multi-ethnic study of atherosclerosis. Atherosclerosis. 2015;239(1):101-108. doi:10.1016/j.atherosclerosis.2014.12.044

65. Kazimierczak-Kabzińska A, KajdaniukD, Siemińska L, et al. Selected adipose tissue hormones in the blood of patients with ischaemic cerebral stroke. Endokrynol Pol. 2020;71(1):21-26. doi:10.5603/EP.a2019.0057

66. Saracevic A, Medved I, Hrabric Vlah S, Kozmar A, Bilic-Zulle L, Simundic AM. The association of systemic inflammatory markers with indicators of stress and cardiac necrosis in patients undergoing aortic valve replacement and revascularization surgeries. Physiol Res. 2020;69(2):261-274. doi:10.33549/physiolres.934243

67. Peller M, Kapłon-Cieślicka A, Rosiak M, et al. Are adipokines associated with atrial fibrillation in type 2 diabetes? Endokrynol Pol. 2020; 71(1):34-41. doi:10.5603/EP.a2019.0059

68. Samanidis G, Gkogkos A, Bousounis S, Alexopoulos L, Perrea DN, Perreas K. Blood plasma resistin and atrial fibrillation in patients with cardiovascular disease. Cardiol Res. 2020;11(5):286-293. doi:10.14740/ cr1121

69. Rachwalik M, Obremska M, Zyśko D, Matusiewicz M, Ściborski K, Jasiński M. The concentration of resistin in perivascular adipose tissue after CABG and postoperative atrial fibrillation. BMC CardiovasC Disord. 2019;19(1):294. doi:10.1186/s12872-019-1254-5

70. Rachwalik M, Zyśko D, Diakowska D, Kustrzycki W. Increased content of resistin in epicardial adipose tissue of patients with advanced coronary atherosclerosis and history of myocardial infarction. Thorac Cardiovasc Surg. 2014;62(7):554-560. doi:10.1055/s-0034-1376403 
71. Lin Q, Price SA, Skinner JT, et al. Systemic evaluation and localization of resistin expression in normal human tissues by a newly developed monoclonal antibody. PLoS One. 2020;15(7):e0235546. doi:10.1371/ journal.pone.0235546

72. von Eynatten M, Schneider JG, Hadziselimovic S, et al. Adipocytokines as a novel target for the anti-inflammatory effect of atorvastatin in patients with type 2 diabetes. Diabetes Care. 2005;28(3):754-755. doi:10.2337/diacare.28.3.754

73. Westphal S, Borucki K, Taneva E, Makarova R, Luley C. Adipokines and treatment with niacin. Metabolism. 2006;55:1283-1285. doi:10.1016/j. metabol.2006.07.002
74. Krusinova E, Klementova M, Kopecky J, et al. Effect of acute hyperinsulinaemia with and without angiotensin II type 1 receptor blockade on resistin and adiponectin concentrations and expressions in healthy subjects. Eur J Endocrinol. 2007;157(4):443-449. doi:10.1530/ EJE-07-0034

75. Corbetta S, Angioni R, Cattaneo A, Beck-Peccoz P, Spada A. Effects of retinoid therapy on insulin sensitivity, lipid profile and circulating adipocytokines. Eur JEndocrinol. 2006;154(1):83-86. doi:10.1530/ eje.1.02057 